\title{
Waiting for a house or building your own? Reconsidering state provision, aided and unaided self-help in South Africa
}

\author{
Karina Landman ${ }^{\mathrm{a}, *}$, Mark Napier ${ }^{\mathrm{b}, 1}$ \\ ${ }^{a}$ Room R2-7, Building 8, South Campus, Department of Town and Regional Planning, University of Pretoria, Pretoria, Gauteng 0001, South Africa \\ ${ }^{\mathrm{b}}$ Urban Landmark, Office 112, 1090 Arcadia St, Hatfield 0083, Tshwane, South Africa
}

Keywords:

Aided self-help housing

South Africa

People's housing process (PHP)

Housing subsidies

Informal settlements

\begin{abstract}
A B S T R A C T
The Constitution of South Africa guarantees the right to "adequate shelter" for all citizens within available state resources. While government policies and delivery programmes are trying to meet the need, a number of challenges, including increasing urbanisation and levels of poverty are continuously raising the demand. Three parallel streams are emerging in the housing landscape: private sector market related housing (including typical townhouse clusters and security/lifestyle estates), the delivery of public housing (including "RDP" and social housing models) and the emergence of various aided and unaided self-help models (including the "People's Housing Process" of state aided house building and the unaided growth of informal settlements). Despite a tradition of self-help housing in South Africa and a number of formal programmes to promote aided self-help housing, it has not gone to scale. This could be related to a number of challenges inherent in the particular South African context, including the significant role that the state plays in housing delivery, linked to an insufficient consideration of the local market, land supply patterns, land values and housing mix.
\end{abstract}

(c) 2009 Elsevier Ltd. All rights reserved.

\section{Introduction}

Aided self-help housing has a long tradition in South Africa, dating from the colonial era to present day post-apartheid interventions. In spite of this, there has not been a clear pattern to the development of self-help housing practice or ideology, and the acceptance of self-help strategies has not been constant (Parnell \& Hart, 1999) as it often has to compete with other delivery models.

The right to adequate housing is enshrined in the South African constitution, phrased as "the right of access to adequate housing". The Constitution therefore supports the right to 'adequate shelter' to all South African citizens within the means of municipalities to fund and deliver such housing opportunities. In order to meet this mandate, the post-1994 housing policy sets out a variety of programmes and mechanisms to assist low-income households with access to secure tenure, services and starter housing. The targeted housing subsidy (for households earning less than R3,500

\footnotetext{
* Corresponding author. Tel.: +27 12420 6379; fax: +27 124203537.

E-mail addresses: karina.landman@up.ac.za (K. Landman), mark@urbanland mark.org.za (M. Napier).

1 Tel.: +27 12342 7636; fax: +27 123427639 .

2 Article 26 of the Bill of Rights.
}

per month) has become the most important component of the post-apartheid housing policy since 1994, providing a range of capital subsidies to assist low-income families, including projectlinked subsidies (utilised in a normal housing project and offering access to housing and services on an individual basis), consolidation subsidies (a reduced subsidy amount and intended only for the top structure for people who already have serviced land) and institutional subsidies (for rental and co-operative housing). In practice, three delivery types have been utilised, namely formal houses to be owned and built by a formal contractor, houses provided through the People's Housing Process (PHP) with the direct participation of the residents, and institutional housing that focussed on rental or rent-to-buy (Donaldson \& Marais, 2002).

The PHP was identified as one of the seven strategies of the White Paper on Housing in 1994, but only officially launched as a programme in 1998. This entails a support programme to assist people who wish to build or organise the building of their homes themselves, hence qualifying as aided self-help housing. However, in spite of the PHP programme and other initiatives aimed at promoting aided self-help housing, there has not been a large uptake in numerical terms (Napier, 2003). This raises a number of questions. Is self-help housing not appropriate or relevant in postapartheid South Africa, or is the process too difficult to implement and manage? Or are there other options for low-income households that are more viable and sustainable, including unaided 
self-help? Many of these questions remain unanswered and as Mackay (1999) points out, the controversy on the merits and de-merits of aided self-help housing in South Africa has still not been settled.

This paper, reconsiders the aided and unaided self-help habitat in South Africa. It commences with a short background of South Africa and the history of self-housing in the country, followed by an overview of the entire housing landscape, including various housing types and forms of regulation, to understand where selfhelp fits in and to what extent it is performing. This provides the foundation to then look at the future of self-help housing in South Africa through a discussion of the key challenges influencing prevalence of self-help housing.

\section{Background and context: a tradition of aided self-help housing in South Africa}

Aided self-help housing generally revolves around the idea that governments might help families to build their own homes (Harris, 1998). While the first signs of self-help housing emerged in Sweden in the beginning of the twentieth century, the first consistent policy and associated theory of self-help housing only emerged in the 1940s. During this time, Puerto Rico became the first area to include aided self-help housing as a central component of their housing policy. This was promoted by the American government and in particular, by the then Assistant Director of US Public Housing Administrator, Crane, who promoted aided selfhelp housing worldwide (Harris, 1998). The writings of Turner (1966, 1972, 1976) prompted a resurgence of interest in self-help housing in the 1960s and contributed to the international rise of self-help housing in the 1960s and 1970s.

While advanced capitalist countries have tended to overlook the notion of self-help housing, it has been a dominant theme in contemporary urban development in the developing countries (Parnell \& Hart, 1999) and most governments in poor countries are encouraging self-help production (Gilbert, 1999). In Africa, people living in cities have mostly been housed under conditions referred to as self-help schemes (Stren, 1978). However, the terms and conditions under which self-help is advocated vary greatly both in time and space (Parnell \& Hart, 1999).

In general, self-help housing is depicted as a cost-effective response to mass urbanisation and the inability of the state to house growing urban populations (Parnell \& Hart, 1999). However, Gilbert (1999) warns that the self-help housing process is highly flawed and cannot be recommended for its efficiency or for its fairness. Mitlin (2001) also points out that self-help housing improvements can be problematic for the poor if they are engaged in income generation activities that are time-consuming and important for livelihood needs.

Self-help housing is not new to South Africa. There is a long and varied usage of self-help policy in the country, dating back to the colonial era where the preference was for owner-built housing for Africans to save costs. After the formation of the Union of South Africa, self-help housing was debated as one of the options in formulating a national urban policy for African people. The postwar housing crisis in Johannesburg gave rise to the development of an emergency site-and-services scheme for 10000 squatter families in Soweto. In the 1950s incremental self-building on serviced sites was considered the cheapest and most efficient solution to overcrowding and squatting. At the end of the 1970s and in the 1980s self-help housing emerged again as a prominent mode of production and became part of the urban reforms in the dying phase of apartheid when ownership of property by African people was reintroduced (Parnell \& Hart, 1999). Therefore, even before 1994, certain types of self-help had been attempted. This occurred through three typical formats, namely site-and-services schemes, core housing schemes and informal settlement upgrading (Napier \& Meiklejohn, 1997). Between 1990 and 1994 standardised services sites were delivered by the Independent Development Trust at scale to approximately 100000 qualifiers of capital subsidy (Huchzermeyer, 2001, p. 309).

The post-apartheid government inherited a shelter crisis in 1994 and again self-help housing gained prominence as a solution. Due to high levels of poverty, fiscal constraints and a growing but not booming economy, it was not possible to provide houses to all those in need. The state's subsidy of R15,000 could only provide a serviced site and a small core shelter with basic services. Individuals had to extend the top structure themselves. Hence, selfhelp housing based on secure tenure and a small government grant once again became the official policy for how to deliver housing to the poor (Parnell \& Hart, 1999).

This gave rise to a new debate in the 1990s and the merits of self-help housing were again debated in post-apartheid circles (Bond, 1999; Bond \& Tait, 1997; Huchzermeyer, 2001; Jenkins \& Smith, 2001; Napier \& Meiklejohn, 1997; Parnell \& Hart, 1999). While some critiques stressed the over-emphasis on the market (Bond \& Tait, 1997), others raised questions about the inflexible nature of the policy disabling mixed tenure (Gilbert, Mabin, McCarthy, \& Watson, 1997) and the inappropriate location of state assisted housing that reinforced Apartheid spatial patterns (Crankshaw \& Parnell, 1996). In addition, there were still many who criticised 'toilet towns' and called for 'real houses' (Huchzermeyer, 2001; Mackay, 1999; Nuttall, 1997). In 1995, the Minister of Housing created uncertainty about the future of self-help housing when she said that "incremental housing" was not an adequate approach for low-income families and would lead to squatter problems (Sidiropolos cited in Mackay, 1999, p. 393). However, in 1998, a subsequent Minister of Housing, upon introducing the PHP programme, increasingly expressed her reliance on this process of house construction: "More emphasis would be placed on people building their own homes using subsidised materials", whereas "government would focus on providing people with the necessary infrastructure" (cited in Huchzermeyer, 2001, p. 323). In another statement, the Housing Minister declared

We aim to go back to our communities and advanced the people's housing process. Where people have developed innovative approaches and solutions, there is an opportunity for us to work with them (cited in Huchzermeyer, 2001, p. 323).

This emphasis was against the context of mass state housing delivery using private sector contractors to deliver houses largely without direct inputs from future residents.

Despite some initial reservations by the South African government, self-help housing as an approach has continued to be actively promoted by many donor organisations and non-governmental organisations (NGOs) in South Africa. The Homeless People's Federation conceptualised a revolving fund providing credit to the poor. This concept was implemented in 1993 and in 1994 an umbrella for the savings group was formalised as the South African Homeless People's Federation, supported by the NGO People's Dialogue. The Federation rejected sites and services and highlighted the need for people-centred development and low interest credit to lower income households. They proposed the concept of Housing Support Centres as vehicles for people-centred developed. This approach of the Homeless People's Federation has been associated with "sustainable" housing. It entails building community trust and the transfer of skills, while ongoing access to credit means the progressive improvement of the housing environment. This approach was recognised by international organisations such as UNCHS (Habitat) and UNDP at the time of the Habitat II 
Conference in 1996 and subsequently led to UNCHS (Habitat), UNDP and USAID support in South Africa for the promotion of a housing process based on mutual- and self-help construction through housing support centres. They partly funded the establishment of the Housing Partnership Trust based in the Department of Housing to capacitate provincial and local spheres of government and NGOs to support people's processes towards housing delivery (Huchzermeyer, 2001).

The Development Action Group (DAG), a well-recognised NGO, in South Africa, actively promotes self-help housing and specifically the PHP. DAG believes that the PHP is a

“... self-help housing mechanism which allows groups of people to work together to pool their resources and contribute their labour to build homes. By supplementing the standard housing subsidy with savings, additional loans or labour, communities implementing PHP are able to build bigger, better homes. The PHP process also builds human capacity and brings communities closer together." (DAG website, 2006).

Another NGO, Planact, also supports the PHP and highlights a number of benefits resulting from this process:

$\bigcirc$ Houses are generally larger and better designed to suit household needs

$\bigcirc$ More choice, creativity and community involvement

$\bigcirc$ Builds the notion of citizenship and pride

Supports the creation of partnerships

$\bigcirc$ Maximises empowerment and participation

$\bigcirc$ Promotes individual choice

$\bigcirc$ Secures tenure and adequate shelter

$\bigcirc$ Creates housing and skills development and opportunities for women

Higher levels of beneficiary satisfaction

$\bigcirc$ Higher levels of project sustainability (Himlin \& Mogatle, 2006).

The NGO Afesis-corplan also actively promotes self-built housing:

"the positive aspect to these self-built houses is that they'll be on land to which they [residents] have secure tenure and they have access to basic services; and in a neighbourhood with a range of social facilities, services and spaces. These households can also slowly begin to upgrade their houses provided that government introduces new ways to support this upgrading"(Eglin, 2007, p. 1).

Despite this support from international organisations and NGOs, self-help housing has not gone to scale in South Africa. By 2002, only about $1 \%$ of state provided houses had been delivered using this aided self-help (Napier, 2003). While part of it may be due to exceedingly bureaucratic procedures that makes it difficult for communities to control the process (Huchzermeyer, 2001) or due to the lack of time available for even under-employed people to become involved, there may also be additional reasons for the slow uptake in the post-apartheid era. In order to explore this further, it is necessary to undertake a brief overview of the current housing delivery patterns to highlight the relationship of self-help housing with the entire housing landscape and market.

\section{The delivery of housing in post-apartheid South Africa}

The delivery of housing in post-apartheid South Africa is characterised by three streams of provision and allocation that are running parallel and often overlapping to some extent. These three streams are private sector built; public sector provided and selfprovided housing.

\section{Private sector housing}

Private sector built housing refers to housing that is delivered and/or financed by the private sector, including typically large scale housing developments by large developers where the individual houses are then sold to households (often financed through a large financial institution or bank) on the open market. Private sector market housing also includes individuals having houses built by a contractor and most often mortgage financed. According to Gardner (2004) private sector housing for ownership comprises $27.2 \%$ of the total stock in South Africa, with private rental constituting 11.5\% (based on the 2001 Census). These typically include low density residential neighbourhoods with single houses on a stand (typical suburbia), apartments, townhouse clusters or complexes, large security or lifestyle estates and mixed developments. One of the significant factors influencing this sector is the high level of insecurity and fear of crime in South Africa. As a result secure apartments, townhouse complexes and large estates have become the predominant model for delivery in this stream. These secure developments typically include large perimeter walls or fences, access control, and private security in the more upmarket developments. It also includes the development of large luxury gated communities for high income households.

House price data indicated that the cheapest house on the formal market, or formal market entry housing, exceeds R200,000, requiring a monthly income of over R11,000 on a loan installment of $\mathrm{R} 3,400$. This monthly loan repayment is almost equal to the monthly household income of $64 \%$ of the country's households (Rust, 2006). While data is not available regarding the percentage of households earning more than R11,000 per month, it is known that only $19 \%$ earn more than R8,000 per month. This means that more than $81 \%$ of South Africa's households are not currently accommodated in formal, commercial private sector housing supply (Royston, 2008) and are therefore dependent on other means and mechanisms to access housing.

In the last 5 years, commercial banks have signed a Financial Sector Services Charter with government, promising to provide mortgages for housing to lower income households. The Banks have pledged R42 billion to be released into the affordable housing market by 2008 in order to assist those who receive little or no government subsidy, including nurses, teachers and the police to access housing loans and housing ownership. In 2008, the outgoing Housing Minister proclaimed that that according to the Banking Associations' calculations, an estimated 32 billion has been expended out of the 42 billion pledged (Budget Vote Speech by Minister Sisulu, 8 June 2007). Credit-linked houses and/or the so-called FSC (Financial Services Charter) houses have therefore started to provide affordable housing options to many lower middle income households. In addition, FSC housing is increasingly being utilised by developers in medium density, mixed (income) developments, alongside RDP and market rate housing, for example in the Pennyville project in the City of Johannesburg (Landman, Mmonwa, Matsebe, \& du Toit, 2009b).

\section{State housing}

In order to address the housing shortage and lack of affordability, the government instituted a number of programmes and mechanism to assist lower income households. These include the subsidy system as mentioned before, as well as other innovative mechanisms to encourage the increase of affordable housing. 
The subsidy system facilitates the provision of a range of housing types. RDP housing (named after the Reconstruction and Development Programme initiated to promote delivery in 1994) is developed by government and allocated to beneficiaries with a household income of less than R3,500. Beneficiaries of this subsidy receive a once off grant for land, basic services (water and sanitation) and the house (top structure). In 2001, the government had provided subsidies for more than 1334200 households with secure tenure (Gilbert, 2004, citing the National Department of Housing), while the government indicated in 2004 that 1.6 million subsidy houses had been provided (Breaking New Ground, 2004, p. 4). According to Gardner (2004) subsidy housing for ownership comprise $15.2 \%$ of the total stock in South Africa, with social housing (rental) constituting $0.5 \%$ and co-operatives $1.6 \%$ (based on the 2001 Census). Medium density housing for rent, referred to as "social housing" in the South Africa context, has significantly increased since then, but still constitutes a small percentage of the overall housing supply in the country. Other forms of state provided housing include public housing at a local level. According to Gardner (2004) ex-council housing (now owned) comprised 7.6\% of the total stock in South Africa, with current council owned housing available to rent, also constituting 7.6\% (based on the 2001 Census).

RDP housing typically includes a stand-alone house of about $30-40 \mathrm{~m}^{2}$ on a $250 \mathrm{~m}^{2}$ plot. However, recently, developers and designers have started to experiment with alternative housing types where RDP units are semi-detached and located on smaller sites to accommodate densification, for example in projects such as the Alexandra Urban Renewal Programme and the Pennyville Development in the City of Johannesburg. In Pennyville, the developers have also built semi-detached RDP units on two levels (i.e. semi-detached simplexes), while in another project in the Nelson Mandela Metropolitan Municipality, namely Sakhasonke, semi-detached duplexes were built. These houses are significantly larger $\left(46 \mathrm{~m}^{2}\right)$. This shows some flexibility regarding the implementation of subsidy housing for ownership.

There is currently very little supply of housing for households earning between R3,500 and R8,000. These households do not qualify for a housing subsidy, yet are unable to afford housing in the market. This gap in the housing market is known as gap housing (Rust, 2006). In order to address part of this gap, housing institutions are also making use of institutional subsidies to co-fund the development of social housing units for the more affordable housing market sector; hence addressing the gap market. Good examples include the Brickfields and Carr Gardens projects developed in the inner city of Johannesburg, and the Amalinda housing project in the Buffalo City Municipality.

The majority of government-delivered dwelling units are concentrated in the urban sector (Cross, 2008). As mentioned in the introduction, households or communities can also apply for a housing subsidy to build their own houses through the PHP.

\section{Self-help housing}

The People's Housing Process is an official self-help housing mechanism which allows groups of people to work together to pool their resources and contribute their labour to build homes. By supplementing the standard housing subsidy with savings, additional loans or labour, communities implementing PHP are, according to support organisations working on such projects, able to build bigger, better homes (DAG website). Given this, the new housing plan acknowledges that the main benefits of the PHP arise from allowing beneficiaries to make choices and exercise control over the housing process. This could ensure that the subsidy is converted into maximum output at the housing 'citizenship' is developed through inclusion in the human settlement development process (Breaking New Ground, 2004, p. 18).

PHP housing includes a variety of housing types and sizes. For example, semi-detached and detached brick houses of $42 \mathrm{~m}^{2}$ (larger than the conventional $36 \mathrm{~m}^{2}$ ) were implemented in Netreg, Cape Town and $42 \mathrm{~m}^{2}$ concrete block detached houses in Mfuleni, Cape Town (Lizarralde, 2008). A recent survey for the Integrated Planning, Development and Modelling Project for the Department of Science and Technology (DST), ${ }^{3}$ indicated that owner-built participated housing delivery through the PHP varies substantially by area, since the delivery modality is not standardised at a national level. Some houses are built by owners themselves with assistance from municipalities and provinces in finding and acquiring land and materials. Others are built by local contractors trained for the community under the PHP and then hired by the owner to build the required house (Cross, 2008, p. 28).

An important issue that arose from the responses to the DST survey is the rise of self-built housing stock (whether delivered through PHP or other processes), both in rural and urban case study areas. There are two major findings in this regard. Firstly, self-build informal high-quality housing is said to be gaining ground rapidly. Under the Polokwane principles of $2007,{ }^{4}$ government renewed its commitment to encourage self-build housing alongside official government housing. Formal-quality owner-built informal brick housing represented $36 \%$ of the housing stock recorded in the specific case study areas, against $10 \%$ percent for subsidy housing. Secondly, self-build high-quality informal housing appears to be a dominant category in both rural and urban settlement types. Owner-built housing of the same quality as formal housing stock is widely reported in the 2008 DST survey data (referred to above) across all the settlement types with owned housing, including in the old townships (Cross, 2008, pp. 60-61). Interestingly, the survey also indicated that in spite of the presence of a large number of self-help houses, less than $1 \%$ of total estimated housing stock surveyed comprised customised PHP projects (Cross, 2008, p. 27). The findings are however based on one study and this need to be confirmed on a larger scale to verify the claim that self-built housing is indeed gaining ground rapidly.

This study furthermore indicated differences between rural and urban self-development areas. In rural areas, self-development areas of owner-built housing appear to be a relatively new form of settlement emerging in the outlying rural sector, comprising informal moderate to good quality housing occupying land obtained on an informal basis. These areas appear to be established initially without infrastructural services, but services are then supplied by the nearest municipality upon receipt of letters of authorization from the traditional leaders. Many of these houses take the form of squared structured brick houses with asbestos roofs. In contrast, urban self-development areas often appear to be on old site-and-services schemes developed in the 1980s, in which families have built their own homes and consolidated them over time as the family income has grown (Cross, 2008, pp. 28-30).

\footnotetext{
${ }^{3}$ This project was commissioned by DST and managed by the CSIR Built Environment. The work was carried out by the CSIR and the HSRC, who was responsible for the survey in particular. The HSRC sampled 2968 cases and extrapolated these for the entire population (based on a detailed demographic study) for the entire study area. They also identified a housing typology that could be linked to the 2001 Census data. The link to the Census has been created by programming Census variables from the national dataset to approximate survey findings, updating the 2001 data to generate the framework for creating settlement typology for any locality in South Africa. Establishing these data definitions usable with the Census allows complete national coverage (Cross, 2008, p. 13).

4 This refers to the resolutions made by the ANC at the 2007 National conference and more specifically resolution 77: "Government considers assisting people with building material to encourage self involvement in the provision of housing needs."
} 
Self-help housing can also include informal backyard shacks in old township areas or new RDP developments or shacks in informal settlements. According to Gardner (2004) informal rental housing, often by renting a backyard shack, comprised 11.4 of the total stock in South Africa, with squatting constituting 12.3\% (based on the 2001 Census). There are often ambiguities contained in the terms "informal housing" and "informal settlements" and for some informal housing refers to shacks, irrespective of whether they are located in squatter settlements, backyards of formal housing or on serviced sites. However, for those who do not qualify for a housing subsidy, a shack in informal settlements remains one of the limited alternatives. Access is often achieved through illegal land invasions at a scale of approximately $10 \%$ of large urban populations (Huchzermeyer, 2001, p. 323). The number of people living in informal settlements and backyard shacks increased from 1.45 million in 1996-1.84 million in 2001, indicating an increase of 26\% (Breaking New Ground, 2004, p. 4) and is more recently being estimated to be around 2 million (Del Mistro \& Hensher, 2009, p. 1).

\section{The emerging housing landscape}

From this discussion, it is clear that the delivery of housing in post-apartheid South Africa is characterised by three streams of delivery, namely private sector housing, state housing and self-help housing (Fig. 1). These three align more or less with who distributes or allocates the land and housing, whether that be market allocation, state allocation or self allocation. The boundaries between these three streams are however, often blurred as many delivery models overlap two categories. Housing being built under the Financial Services Charter (FSC housing) and credit-linked housing for example are privately delivered and owned with the state providing guarantees for the loans; hence it is a state enabled process with private sector leading. PHP projects, on the other hand are financed by the state, while the beneficiaries are expected to build the house themselves; hence providing a viable mechanism for aided self-help housing. These housing models are regulated and usually follow formal planning procedures during their implementation that includes the delivery of infrastructure and services prior to the construction of the houses.

In addition, the emerging housing landscape also presents a range of unaided self-help housing that is often unregulated and occurs informally outside the formal planning processes. This includes the construction of backyard shacks in formal RDP developments or old township areas, or within informal settlements. While the shacks are informally built (without council approval), but with the consent of the owner of the township house (often to generate additional income), free standing informal settlements are mostly the result of land invasions, where the housing is established without infrastructure and services. Depending on various factors, including the location of the settlement, land suitability and ownership, the municipality may in time decide to upgrade the settlement and provide infrastructure and services. The upgrading of informal settlements is indeed one of the government's high priority programmes as they aim to 'eradicate' all informal settlements by 2014 and provide houses to those currently living in informal housing in South Africa. However, while the current policy is to deliver a choice of housing alternatives, in practice 'a house on a fully serviced property with freehold title' is seen as one of the only alternatives (Del Mistro \& Hensher, 2009, p. 1). The preference for contractor built and completed houses that are fully serviced and owned by the residents, were also reiterated to a large extent in a recent study on medium density mixed housing conducted by the CSIR in South Africa (Landman et al., 2009b; Landman, Mmonwa, Matsebe, \& du Toit, 2009c).

This raises many questions about the future of self-help housing in the country. The discussion has indicated that there are currently a number of models prevalent in South Africa and that self-help can be formal (regulated) or informal (self- or unregulated). In addition, it can also vary between urban and rural locations. And while one recent study highlights a possible increase in self-help housing, it is still evident that formal, aided self-help housing (delivered through the PHP) process constitutes a very small percentage of the current housing stock and a small part of self-help housing per se. In addition, it was indicated that there is no lack of support for selfhelp in South Africa. There is a strong support from international organisations and local NGOs for aided self-help and some political backing. Lastly, a number of NGOs proclaims the benefits of selfhelp housing, including a larger house, more choice and increased community participation. It therefore begs the question as to why there is such a low scale of uptake of aided self-help in postapartheid South Africa.

\section{The future of aided self-help in South Africa}

The future of aided self-help housing is largely influenced and dependent on the role of the state in South Africa, not to mention the ability of civil society organisations to demand self-help participation. The previous ANC administration tended to focus on state enablement of subsidised housing to qualifying households, but has more recently taken a 'big-state' approach that suggests greater state involvement in direct provision. The result has been the domination of RDP housing in the emerging affordable and low-income housing landscape - effectively exerting an outward pressure on other delivery models to both sides, including bank mortgaged and credit-link housing on the one side, and PHP on the other (Fig. 2). This dominance of state allocated housing is as

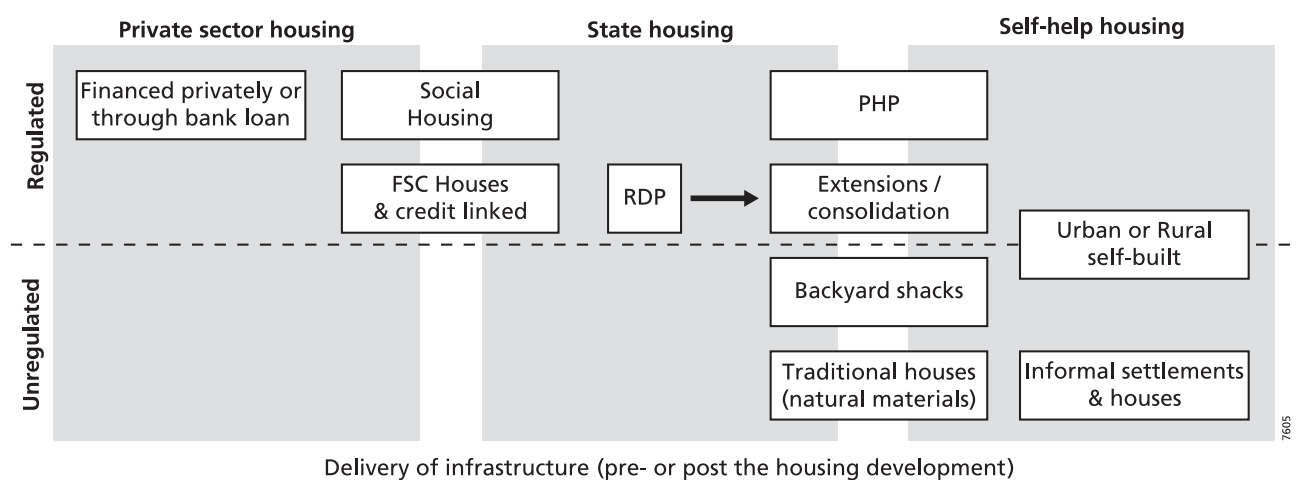

Fig. 1. Emerging housing landscape with three parallel streams of housing delivery. 


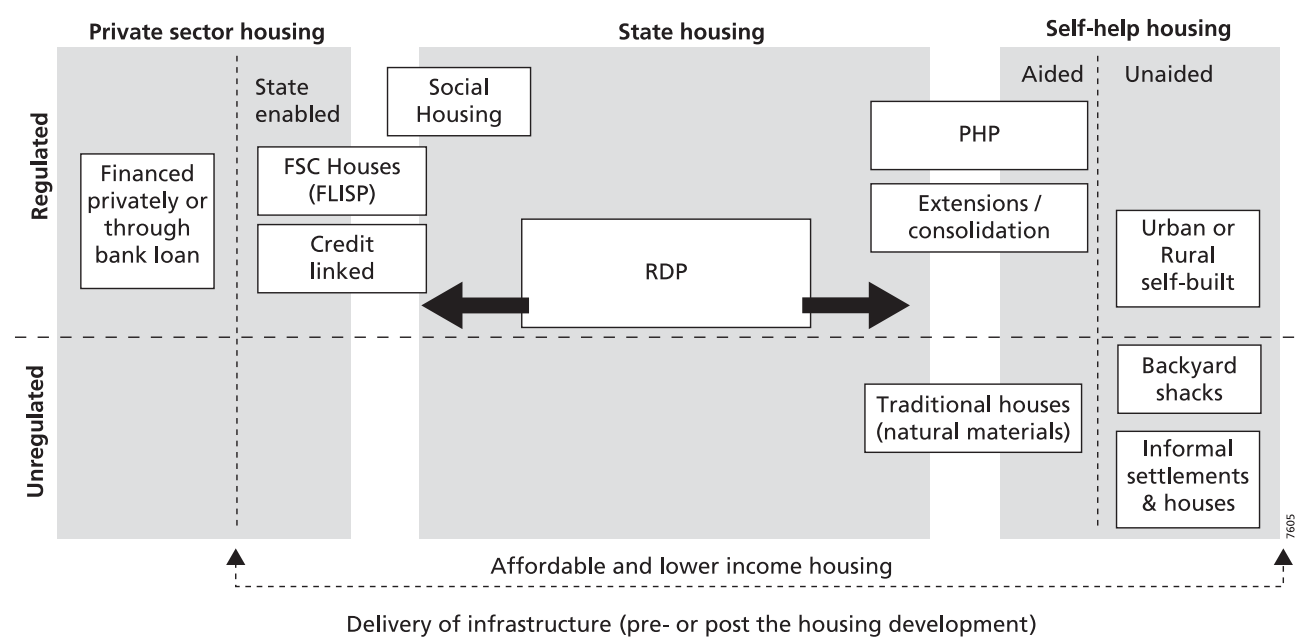

Fig. 2. The role of state delivery in relation to the delivery of affordable and lower income housing.

a result of the increased expectations from potential beneficiaries, where a fully subsidised and completed house (so-called 'giveaway houses') is preferred above self-built options that require some physical input (sweat equity) or some financial equity.

It is difficult also for banks building housing for low-income households at the upper end of the state allocation band to differentiate their housing product enough to attract people to take formal finance to fund their houses. It is easier to depress ones income and therefore qualify for the 'free' state allocated houses. Similarly, PHP takes a significant investment of time and labour on the part of the residents, and a greater investment of administrative capacity by the state. Ironically therefore, the efficiency of state delivery of housing in South Africa has left less space for aided selfhelp housing where in other countries less state intervention allows self-help to be the main source of formal low-income housing production.

This situation has also meant that organisations promoting micro-finance using models developed in other African and Asian countries have had little uptake in South Africa (see also Bauman, 2001).

The dominance of state allocated housing also creates a precedent for different spheres of government, an acceptable way of addressing the issue of low-income housing that appears to overshadow the engagement of various sectors with other delivery models. As the project-linked subsidy lends itself to mass-delivery at scale, many provincial departments have increasingly supported this approach to boost their delivery numbers (Huchzermeyer, 2001).

What does this mean for the future of self-help housing? Firstly, it is important to distinguish between various types of self-help housing. State enabled and aided self-help housing is likely to produce a smaller proportion of the total housing stock, unless a number of challenges are recognised and addressed.

- Blind to markets: As was indicated before, the South African housing market excludes large numbers of people from participating directly and benefitting from its operation (Rust, 2006). As such, both banks and government have recognised that the conventional mortgage loan system is too complex and expensive for the low-income market (Bauman, 2001; Huchzermeyer, 2001). Given this, state allocated (subsidy) houses offer an efficient mechanism to bypass many of these complexities and provide a reasonable house without any input required from the beneficiaries. This state allocation of houses is not market driven but as soon as ownership of the housing passes to the residents or landlords, they become part of the housing and land market for future exchanges.

- Blind to land supply and land values: There is also a lack of sufficient well-located and affordable land, especially in fast growing urban areas (Napier, 2009). In addition, land prices also increased substantially over the last few years. Nominal land prices increased by $17.3 \%$ to approximately R280,200 on average during the second quarter of 2006, compared to $22.9 \%$ in the first quarter (Brown-Luthango, 2007). This inevitably leads to competition for land and increased land value of well-located land, making it almost impossible for low-income households to access land, unless invaded illegally, or for the state to acquire such land on behalf of poorer communities. Hence, more and more households that do not qualify for housing subsidies, including nonSouth African citizens, have to revert to unaided self-help options such as low cost renting in older inner city buildings or backyard shacks (formally or informally), or building a shack in an informal settlement and hoping for in-situ upgrading or relocation to a formal RDP house as part of the government's programme to upgrade all informal settlements by 2014 .

- Blind to mix: There also appears to be some resistance to an unregulated or informal mix of tenure. While the new housing plan, Breaking New Ground (2004) promotes formal mixed tenure and mixed income developments, many questions are asked about informal mixed tenure practices such as backyard rental to supplement income. In a recent CSIR study, residents of mixed developments expressed a concern about the emergence of home-based enterprises in the RDP section, as they were of the opinion that this could increase levels of informality within the development (Landman, Mmonwa, Matsebe, \& du Toit, 2009a, Landman et al., 2009b, 2009c).

Aided self-help in South Africa often works best interspersed with other development types. That is why a healthy mix within developments is worth trying to achieve. In a community which is benefitting from state allocated RDP houses, there are often a subgroup of households for whom direct involvement in the development and building process is seen as leading to a better outcome. If a real choice is given to communities, often with the involvement of a proactive housing NGO, some households do choose to go the self-help route. However, that also requires a supportive municipality and project developers willing to work with this mix. 


\section{Conclusion: waiting for a house or building your own?}

This paper has indicated that there is a long tradition of aided and unaided self-help housing in South Africa and that the debate about the potential and merits of aided self-help is still alive and well in South Africa. Yet, in spite of expressed political support and strong support by international donor organisations and local NGOs, as well as increased benefits related to PHP houses, it has not gone to scale in the country.

The paper argues that this has to be understood against the backdrop of three emerging streams of housing delivery in the housing landscape, namely private sector market related housing (including typical townhouse clusters and security/lifestyle estates), the delivery of public housing (including "RDP" and social housing models) and the emergence of various aided and unaided self-help models (including the "People's Housing Process" of state aided house building and the unaided growth of informal settlements).

If the housing landscape is also seen as competition over scarce resources, in this land for housing, then the three dominant modes of production and allocation relate to one another directly. Each form of production exerts pressure on the others, and aided selfhelp housing has to take its place within that context.

As state delivered subsidy or RDP houses continues to dominate the landscape in terms of housing provision for lower income households, it is unlikely that PHP initiatives will gain significant ground while the state programme remains efficient. Given the fact that the new ANC administration is also generally going for a "big state" approach, it is not likely that the situation in South Africa will change significantly in the immediate future. It may therefore result in a situation, due to increased expectations and inherent complexities related to alternative self-help models, where lowincome households will rather wait for a state provided house than building their own.

However, the exception may be those households that do not qualify for a subsidy, for example due to previous allocations in rural areas or not being a South African citizen. For these households, informal or shack accommodation may be the only alternative for the time being, and the consolidation of that housing will be an essentially self-help process with or without state assistance. Given this, it is likely that unaided self-help housing, including informal settlements and backyard shacks, will be a factor to contend with for some time.

The encouraging aspect is that today's state allocated stock is tomorrow's housing and land market, as residents become players using their assets for poverty alleviation. Today's land invasion is tomorrow's housing backlog, which the South African state is addressing by improving informal settlement upgrading processes.

In conclusion, aided self-help has a role to play in South Africa within all of these delivery modes, but its extent and scale of implementation would depend on the dominance of other housing initiatives in the country and the way the market as a whole operates for various groups, how quickly land becomes available for lowincome housing and the acceptance of self-help housing models by communities.

\section{References}

Bauman, T. (2001). Microfinance and poverty alleviation in South Africa, Bay Research and Consultancy Services, August 2001. Bay Research and Consultancy Services has prepared this discussion document as a conceptual input into the process of developing an appropriate microfinance policy for the Department of Social Development.

Bond, P. (1999). Basic infrastructure for socio-economic development, environmental protection and geographical desegregation: South Africa's unmet challenge. Geofroum, 30, 43-59.
Bond, P., \& Tait, A. (1997). The failure of housing policy in post-apartheid South Africa. Urban Forum, 8(1), 19-41.

Brown-Luthango, M. (2007). Voices of the poor: literature review. Developed for urban landmark. Accessible on www.urbanlandmark.org.za.

Crankshaw, O., \& Parnell, S. (1996). Housing provision and the need for an urbanisation policy in the new South Africa. Urban Forum, 7, 90-100.

Cross, C. (2008). Profiling housing demand: Settlement typology and survey results. Report prepared for the demonstrator Toolkit for Integrated Planning, for the Department of Science and Technology. CSIR Report no: CSIR/BE/PSS/ER/2008/ 0048/B.

Del Mistro, R., \& Hensher, D. A. (2009). Upgrading informal settlements in South Africa: policy, rhetoric and what the residents really value. Housing Studies, 24 (3), 333-354.

Donaldson, R., \& Marais, L. (2002). Urban policy for urban change during transition: an introduction. In Donaldson., \& Marais. (Eds.), Transforming rural and urban spaces in South Africa during the 1990s: Reform, restitution, restructuring. African Century Publications. Series no 10

Eglin, R. (February/March 2007). Stark choices confront housing. The Local Government Transformer, 13(1)

Gardner, D. (2004). Sharpening the focus. A new look at South Africa's housing strategy. Presentation prepared for the Housing Finance Resource Programme.

Gilbert, A. (1999). A home is for ever? Residential mobility and homeownership in self-help settlements. Environment and Planning A, 31, 1073-1091.

Gilbert, A. (2004). Helping the poor through housing subsidies: lessons from Chile, Columbia and South Africa. Habitat International, 28, 13-40.

Gilbert, A., Mabin, A., McCarthy, M., \& Watson, V. (1997). Low-income rental housing: are South African cities different? Environment and Urbanization, 9(1), 133-148.

Harris, R. (1998). The silence of the experts: 'aided self-help housing', 1939-1954. Habitat International, 22(2), 165-189.

Himlin, B., \& Mogatle, S. (4-5 August 2006). NGOs and the People's housing process in South Africa: the case of Vosloorus. Presented at the Conference NGOs as Innovators and Agents of Change: A History Interpreted by Development Practitioners, Hosted by Planact at the University of the Witwatersrand.

Huchzermeyer, M. (2001). Housing for the poor? Negotiated housing policy in South Africa. Habitat International, 25, 303-331.

Jenkins, P., \& Smith, H. (2001). An institutional approach to analysis of state capacity in housing systems in the developing world: case studies in South Africa and Costa Rica. Housing Studies, 16(4), 485-507.

Landman, K., Mmonwa, M., Matsebe, G., \& du Toit, J. (2009a). Medium density mixed housing in South Africa: The case of Amalinda. CSIR Research Report.

Landman, K., Mmonwa, M., Matsebe, G., \& du Toit, J. (2009b). Medium density mixed housing in South Africa: The case of Pennyville. CSIR Research Report.

Landman, K., Mmonwa, M., Matsebe, G., \& du Toit, J. (2009c). Medium density mixed housing in South Africa: The case of Sakhasonke. CSIR Research Report.

Lizarralde, G. (2008). Unexpected negative outcomes of community participation in low-cost projects in South Africa. Habitat International, 32, 1-14

Mackay, C. J. (1999). Housing policy in South Africa: the challenge of delivery. Policy Review, 14(3), 387-399.

Mitlin, D. (2001). Housing and urban poverty: a consideration of the criteria of affordability, diversity and inclusion. Housing Studies, 16(4), 509-522.

Napier, M. (2009). Making urban land markets work better in South African cities and towns: arguing the basis for access by the poor. In S.V. Lall, M. Freire, B. Yuen, R. Rajack, J.-J. Helluin (Eds.), Urban land markets: Improving land management for successful urbanization. Dordrecht: Springer. ISBN: 978-1-40208861-2.

Napier, M. (2003). “Supporting the People's housing process”. In F. Khan, \& P. Thring (Eds.), Housing policy and practice in post-apartheid South Africa (pp. 321-362). Johannesburg: Heinemann Publishers (Pty) Ltd.

Napier, M., \& Meiklejohn, C. (1997). Core housing and incremental growth - Is the vision being realised? Pretoria: CSIR Publication. No: BOU/E9709.

Nuttall, J. (1997). The first five years: The storey of the independent development trust. Cape Town: Independent Development Trust.

Parnell, S., \& Hart, D. (1999). Self-help housing as a flexible instrument of state control in 20th-century South Africa. Housing Studies, 14(3), 367-386.

Royston, L. (2008). How tenure security can increase access to economic opportunities for the poor. Position paper for the second economy strategy project, initiated by the Presidency in South Africa.

RSA Department of Housing (2004). Breaking New Ground: A comprehensive plan for the creation of sustainable human settlements. Policy document. Pretoria: National Dept of Housing. Available online http://abahlali.org/files/Breaking\% 20new\%20ground\%20New_Housing_Plan_Cabinet_approved_version.pdf.

Rust, K. (2006). Analysis of South Africa's housing sector performance. Johannesburg: FinMark Trust.

Stren, R. E. (1978). Housing the urban poor in Africa: Policy, politics and bureaucracy in Mombasa. Berkeley: Institute for International Studies.

Turner, J. (1976). Housing by people: Towards autonomy in the built environment. New York: Pantheon Books.

Turner, J. F. C. (1966). Uncontrolled urban settlement. Problems and policies. United Nations centre for housing, building and planning. New York. In G. Breese (Ed.), The city in newly developing countries. Englewood Cliffs, NJ: Prentice-Hall. 1969.

Turner, J. F. C. (1972). Housing as a verb. In J. F. C. Turner, \& R. Fichter (Eds.), Freedom to build. Dweller control of the housing process (pp. 148-175). 